\title{
Isolation, purification and characterization of protein from Litchi chinensis honey and generation of peptides
}

\author{
Debalina Bose ${ }^{1}$; Manchikanti Padmavati2; Rintu Banerjee ${ }^{1,3 *}$ \\ pur, India \\ ${ }^{2}$ Rajiv Gandhi School of Intellectual Property Law, Indian Institute of Technology Kharagpur, India \\ ${ }^{3}$ Agricultural and Food Engineering Department, Indian Institute of Technology Kharagpur, India
}

${ }^{1}$ P.K. Sinha Centre for Bioenergy and Renewables, Advanced Technology Development Centre, Indian Institute of Technology Kharag-

\section{*Corresponding Author(s): Rintu Banerjee \\ P.K. Sinha Centre for Bioenergy and Renewables, Advanced Technology Development Centre, Indian Institute of Technology Kharagpur, India Email: rb@iitkgp.ac.in \& rb@agfe.iitkgp.ernet.in}

Received: Dec 19, 2019

Accepted: Feb 25, 2020

Published Online: Mar 02, 2020

Journal: Journal of Addiction and Recovery

Publisher: MedDocs Publishers LLC

Online edition: http://meddocsonline.org/

Copyright: (C) Banerjee R (2020). This Article is distributed under the terms of Creative Commons Attribution 4.0 International License

Keywords: Litchi chinensis; Protein; Purification; Characterization; Identification

\section{Abstract}

Objective: Food addiction is an eating disorder affecting the behavioral and neurological condition associated with BMI (Body mass index), BED (binge eating disorder) and obesity in human being. High-calorie foods, especially sugar, have an addictive potential. The conventional treatment processes involving cognitive behavioral therapy, mental health treatments and intake of drugs have acute side effects. The objective of this study was to characterize a high calorie natural food honey, which has been reported to have addictive behavior, and further generate peptides from the protein using enzyme.

Methods: Protein from honey was concentrated by ultrafiltration, purified by ion exchange chromatography, characterized by SDS-PAGE, isoelectric focusing, sequencing and identified by MALDI-TOF/MS analysis.

Results: Ultrafiltration was found to significantly concentrate the protein and chromatographic techniques resulted in purification of protein to homogeneity. The protein having molecular weight of $55 \mathrm{kDa}$ was found to have a pl of 5.5 and hydrophilic $\mathrm{N}$ terminal sequence. The protein was identified as Major royal jelly protein 1, most abundant protein present in honey. Peptides were generated with high antioxidant property.

Conclusion: Protein is a major biomolecule in honey exhibiting biological activities. The characterization of protein in this study helps to get idea of the molecular characteristics so that further studies on the activity can be evaluated. Moreover peptides have got high antioxidant property.

Cite this article: Bose D, Padmavati M, Banerjee R. Isolation purification and characterization of protein from Litchi chinensis honey and generation of peptides. J Addict Recovery. 2020; 3(1): 1016. 


\section{Introduction}

Food addiction, a condition recognized as overeating or eating disorder is related to neurobiological and behavioral issues in which a person becomes addicted to food [1]. Terms like "chocoholic" and "carbohydrate craving" are popularly used to describe man's desire and fondness for food [2]. Certain foods have got addictive potential causing loss of control over food intake resulting in eating-related disorders like binge eating disorder, bulimia nervosa, anorexia, weight gain, and obesity [3-5]. High calorie food, fatty foods and salty foods has been reported to be highly addictive [4], which include food items like coffee, bacon, milk, eggs, pizza, chocolate, cheesecake, and maize $[8,9]$. It has been explained that the brain response for food addiction is similar or as strong as addiction for drugs $[6,7]$. The craving for sugar has been found to be much stronger in comparison to cocaine [10]. The consumption of high calorie food honey, in ancient age and the addiction of sugar in modern age have been found to have evolutionary connection [10].

Besides sugary substances, protein from various food items (milk, rice, spinach, soya, wheat, meat, cereal, and egg)as well as peptides generated from proteins havebeen found to exhibit opioid activity [11]. Bioactive peptides such as gluteomorphine from wheat protein, soymorphine from soy protein, rubiscolin from spinach protein, oryzatensin from rice protein, ovalulin from ovalbumin, $\beta$-casomorphine and lactoferroxin from casein and lactoferrin respectively have been reported by researchers to have opioid activity imparting adverse effect like anxiety, depression, vomiting, dizziness, physical dependence, anhedonia, nausea and addiction in human $[11,12]$.

Peptides and protein from honey have been receiving widespread attention in the scientific community because of its innumerable bioactive properties. These proteins or peptides if possess opioid activity is not well known and thus, was felt essential to know if the protein/peptide present in honey has any role in addiction. However, understanding the addictive behavior of food necessitates its characterization [13]. For production of peptides, proper techniques for purification of protein is apre-requisite which is again necessary for protein characterization $[14,15]$. Detailed study on purified protein is necessary to understand its role in addiction.

Therefore, the present article emphasizes on proper isolation andpurification of protein present in honey along with its characterization. Some purified protein from honey have been successfully identified and is currently a fore runner of the future to addresshealth related issues. In the present article Litchi chinensis honey, abundantly available in India was collected and protein from the honey was isolated, purified and characterized.

Materials and methods

\section{Sample}

Litchi honey (Litchi chinensis) was collected from colonies of Apis mellifera in Baruipur apiculture industrial co-operative society Ltd., Kolkata, West Bengal, India. Honey was then stored in sterilized sealed glass jars at room temperature before use.

\section{Ultrafiltration}

Protein was isolated from honey using physical method of ultrafiltration. Honey sample was dissolved in $0.01 \mathrm{M}$ Tris- $\mathrm{HCl}$ buffer ( $\mathrm{pH} \mathrm{7.4)} \mathrm{and} \mathrm{ultrafiltration} \mathrm{process} \mathrm{was} \mathrm{carried} \mathrm{out} \mathrm{using}$ a $10 \mathrm{kDa}$ polyethersulfone membrane (Sartorious, India) to concentrate and partially purify the protein present in honey. The obtained retentate was recirculated several times until the volume was reduced to approximately one-tenth of the initial. The protein concentration was checked after each cycle. A fraction of the concentrated retentate was subjected to ultracentrifugation at $8000 \mathrm{rpm}$ for $15 \mathrm{~min}$. The process was repeated 3-4 times until the dark pellet formed on the wall of the centrifuge tube was completely removed with the collection of supernatants.

\section{Ion exchange chromatography (IEC)}

The supernatant from the ultrafiltration step was subjected to purification using a Q-sepharose column ( $40 \mathrm{~mm} \times 5.6 \mathrm{~mm}$ ), attached to a BioLogic LP single-step purification system. The cartridge $(5 \times 1 \mathrm{~mL})$ was pre-equilibrated with $0.01 \mathrm{M}$ Tris- $\mathrm{HCl}$ of $\mathrm{pH} 7.4$ (buffer A), into which the concentrated protein was injected. Elution of bound proteins was carried out using buffer $B(0-50 \%, 0.5 \mathrm{M} \mathrm{NaCl}$ in buffer $A)$ at $1.5 \mathrm{~mL} / \mathrm{min}$ flow rate. Absorbances of all fractions were detected at $280 \mathrm{~nm}$ by an online UV detector.

\section{Bradford assay}

Total protein content at each step of purification was checked by the Bradford method [16]. Bovine serum albumin (BSA) was used as standard. Buffer $A$ was used as a blank.

\section{Physico-chemical characterization of purified protein}

\section{Sodium dodecyl sulfate-polyacrylamide gel electrophoresis} (SDS-PAGE)

The extent of homogeneity at each step of purification was detected by SDS-PAGE performed on $12 \%$ resolving gel and $4 \%$ stacking gel following the protocol of Laemmli [17]. Molecular weight $\left(\mathrm{M}_{\mathrm{w}}\right)$ of the purified protein was determined by comparing the relative mobility of standard protein marker of 10-250 kilodaltons (kDa) (Precision Plus Protein Standard, Bio-Rad).

\section{Molecular weight $\left(\mathrm{M}_{\mathrm{w}}\right)$}

The molecular weight of the unknown protein was confirmed by Matrix-Assisted Laser Desorption/Ionization Time-Of-Flight Mass Spectrometric (MALDI-TOF/MS) analysis. Sinapic acid was used as a matrix for the analysis.

\section{Isoelectric Focusing (IEF)}

Rotofor system (Bio-Rad, USA), with a mini focussing chamber $(18 \mathrm{~mL}$ ) equipped with 20 fractionation compartments was employed to check the isoelectric point ( $\mathrm{pl}$ ) of the purified protein. $0.1 \mathrm{M}$ sodium hydroxide and $0.1 \mathrm{M}$ phosphoric acid were used as electrolytes in cathode and anode assembly, respectively. A pH gradient was created using ampholyte (Bio-Lyte $3 / 10$, BioRad, USA) of range 3.0-10.0. Sample solution (18 mL distilled water, $1 \mathrm{~mL}$ ampholyte and $0.5 \mathrm{~mL}$ purified protein) was prepared and loaded into the rotofor chamber. Focusing was performed at a constant power of $10 \mathrm{~W}$ for $4 \mathrm{~h}$. After the complete run, 20 fractions were collected and evaluated for $\mathrm{pH}$ and protein concentration. The pl value was further confirmed by MALDI-TOF mass spectrometricanalysis.

\section{Protein sequencing}

Automated Edman degradation was carried out on a protein sequencer (Model PPSQ-31A; Shimadzu Scientific, Kyoto, Japan) to determine the $\mathrm{N}$-terminal amino acid sequence of the protein. The purified protein was loaded onto a polyvinylidene difluoride (PVDF) membrane (Millipore) by electrophoresis which 
was further stained with Coomassie Brilliant Blue R-250 dye (Thermo Fisher Scientific), destained and washed thoroughly. Stained spots were cut off and sequence analysis was done. Homology search of the obtained sequence was carried out using BLAST (Basic Local Alignment Search Tool).

\section{In-solution digestion of protein}

The purified protein was subjected to in-solution digestion for further identification of unknown protein. Protein sample $(10 \mu \mathrm{L})$ was mixed with digestion buffer $(15 \mu \mathrm{L})$, reducing agent $(3 \mu \mathrm{L})$ and incubated for $5 \mathrm{~min}$ in boiling water. The solution mixture was cooled at room temperature and spin down to collect the supernatant. Alkylating agent $(3 \mu \mathrm{L})$ was further added and incubated in the dark at room temperature for $20 \mathrm{~min}$. Activated trypsin $(1 \mu \mathrm{L})$ was added to the solution mixture followed by overnight incubation at $37^{\circ} \mathrm{C}$. Sample after overnight incubation was boiled for $5 \mathrm{~min}$ and centrifuged at $8000 \mathrm{rpm}$ in a microcentrifuge. The supernatant was then collected for protein identification by MALDI-TOF/MS analysis.

\section{Matrix-assisted laser desorption/ionization time-of-flight mass spectrometry (MALDI-TOF/MS)}

MALDI-TOF/MS analysis and peptide masses were determined on a mass spectrometer (UltrafleXtreme ${ }^{\mathrm{TM}}$, Bruker, Germany). The matrix system used was $\alpha$-cyano-4-hydroxycinnamic acid in acetonitrile $(70 \%, \mathrm{v} / \mathrm{v})$ containing $0.1 \%(\mathrm{v} / \mathrm{v})$ trifluoroacetic acid. Sample matrix $(1 \mu \mathrm{L})$ was used for peptide elution and the peptides eluted were spotted onto the target plate. MASCOT search program was performed for database searches for peptide mass fingerprinting (PMF). The mass spectrometric analysis produced a list of molecular weights of the fragments (peak list). The peptide masses were compared to the protein database Swiss-Prot. The results were statistically analyzed by the software and possible matches were detected.

\section{Enzymatic hydrolysis}

The purified protein was digested using sequencing grade trypsin (Promega, USA) to produce protein hydrolysate or peptides [18]. Trypsin $(0.03 \%, \mathrm{w} / \mathrm{w})$ was added to purified protein fraction for hydrolysis at $37^{\circ} \mathrm{C}$ and $\mathrm{pH} 7.4$ for $24 \mathrm{~h}$. The proteolytic mixture was then boiled for $5 \mathrm{~min}$ and subjected to centrifugation at $8000 \mathrm{rpm}$ for $15 \mathrm{~min}$. The supernatant was then assayed for antioxidant activities.

\section{Bioactive properties}

\section{DPPH (1, 1-diphenyl-2-picrylhydrazyl) assay}

Honey, purified protein, and protein hydrolysate/peptides were subjected to further analysis of antioxidant property[19]. Sample solution was prepared by mixing sample $(0.5 \mathrm{~mL})$ with DPPH ( $4 \mathrm{~mL}, 0.5 \mathrm{mM}$ ) in methanol and incubated for $30 \mathrm{~min}$ in dark. Methanol was used as a blank to measure the absorbance at $517 \mathrm{~nm}$ and results were calculated as percent inhibition of DPPH radical using the formula:

$$
\text { DPPH activity }(\%)=\left[\left(D_{\text {control }}-D_{\text {sample }}\right) / D_{\text {control }}\right] \times 100
$$

Where, $D_{\text {control }}$ is the absorbance of solution without sample and, $D_{\text {sample }}$ is the absorbance of sample solution.

\section{FRAP (Ferric reducing antioxidant power) assay}

Honey, purified protein, and protein hydrolysate/peptides were assayed for reducing power[19]. Each sample $(0.5 \mathrm{~mL})$ was added to $1.5 \mathrm{mLFRAP}$ reagent [acetate buffer $(300 \mathrm{mM} / \mathrm{L}$,
$\mathrm{pH}$ 3.6): TPTZ solution ( $10 \mathrm{mM}$ in $40 \mathrm{mM} / \mathrm{L} \mathrm{HCl})$ : ferric chloride $\left(20 \mathrm{mM} \mathrm{FeCl}_{3} \cdot 6 \mathrm{H}_{2} \mathrm{O}\right)$ at $10: 1: 1$ ratio] and incubated at $37^{\circ} \mathrm{C}$ for $30 \mathrm{~min}$. Distilled water was used as a blank for measuring absorbance at $593 \mathrm{~nm}$. Calibrations were performed using ferrous sulphate solutions (100-1000 $\mu \mathrm{M})$ and results were expressed as micromoles of ferrous equivalent [ $\mu \mathrm{M} \mathrm{Fe}(\mathrm{II})]$.

ABTS [2, 2'-azino-bis (3-ethylbenzothiazoline-6-sulphonic acid)] antioxidant assay

Honey, purified protein, and protein hydrolysate/peptides were assayed for antioxidant activity in reaction with ABTS cation radical [19]. ABTS cation was produced by reacting ABTS stock solution $(7 \mathrm{mM})$ with potassium persulfate $(2.4 \mathrm{mM})$ at 1:1 ratio followed by incubation for $14 \mathrm{~h}$ at room temperature in dark. Before, performing the assay, ABTS radical solution was diluted with methanol to obtain an absorbance of $0.700 \pm 0.05$ at $734 \mathrm{~nm}$. To $0.5 \mathrm{~mL}$ of sample solution $(0.1 \mathrm{~g} / \mathrm{mL})$ equal amount of ABTS solution was added. The absorbance was recorded at $734 \mathrm{~nm}$ after $5 \mathrm{~min}$ against the corresponding blank and percentage decrease in the absorbance was calculated using the formula:

$$
\text { Inhibition of ABTS }(\%)=\left[\left(A_{\text {blank }}-A_{\text {test }}\right) / A_{\text {blank }}\right] \times 100
$$

Where, $A_{\text {blank }}$ is the absorbance of blank sample ( $t=0 \mathrm{~min}$ ) and $A_{\text {test }}$ is the absorbance of test sample at the end of the reaction $(t=10 \mathrm{~min})$.

\section{Results and discussion}

Concentration of protein through ultrafiltration and ultracentrifugation

To isolate the desired protein from honey solution, ultrafiltration (10 kDa cutoff membrane) process was adopted. Concentration and fractionation of protein were carried out by passing the entire solution for several cycles. Molecular weight compounds more than $10 \mathrm{kDa}$ present in honey solution was collected in the retentate whereas the low molecular weight compounds were collected in the filtrate. After several runs, ultrafiltration followed by ultracentrifugation resulted in honey protein concentration that was next employed to purification. The protein concentration at each step of purification is shown in Table 1.

\section{Purification of protein}

The concentrated protein obtained through ultrafiltration and ultracentrifugation was subjected to purification throughanion exchange chromatography where a graph showing two peaks were observedat $280 \mathrm{~nm}$ i.e. peak 1 represented by fractions $4^{\text {th }}-10^{\text {th }}$ and peak 2 represented by fractions $34^{\text {th }}-40^{\text {th }}$.

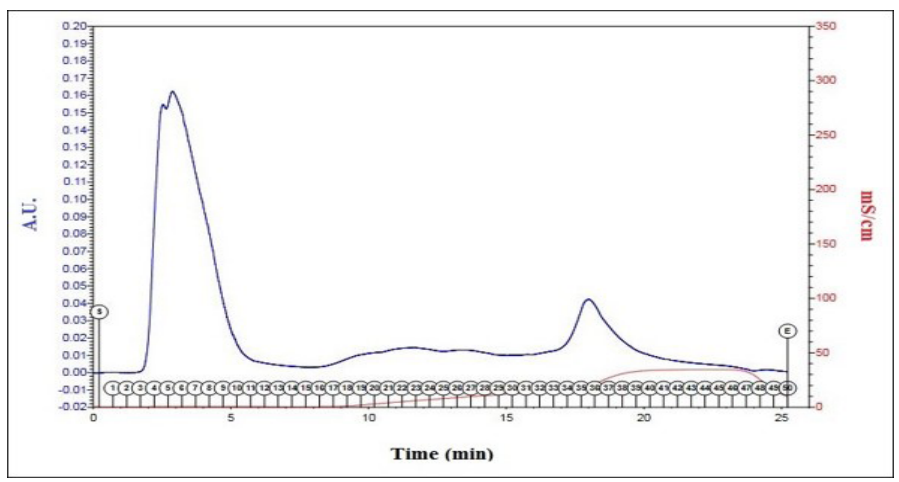

Figure 1: Chromatogram of protein purification by ion exchange chromatography 
The protein concentration of these fractions was measured by Bradford method. Fraction 36 showed a protein concentration of $0.102 \mathrm{mg} / \mathrm{mL}$ while fraction 6 showed a protein content of $0.068 \mathrm{mg} / \mathrm{mL}$.

Table 1: Protein concentration at each step of purification

\begin{tabular}{|c|c|}
\hline Purification steps & Protein concentration $(\mathrm{mg} / \mathrm{mL})$ \\
\hline Crude honey & 0.54 \\
\hline Ultrafiltration (10 kDa Retentate) & 2.88 \\
\hline Ultrafiltration (10 kDa Permeate) & 0 \\
\hline Ion exchange chromatography fraction & 0.102 \\
\hline
\end{tabular}

Fraction 36 showing highest protein content was further checked for degree of purity by SDS-PAGE analysis. Clear protein band of $\sim 53-55 \mathrm{kDa}$ was observed in fraction 36 and purification to homogeneity was confirmed by the presence of a single band in the SDS-PAGE gel (Figure2). Thus, the protein present in highest concentration in the honey was purified and subjected to further characterization.

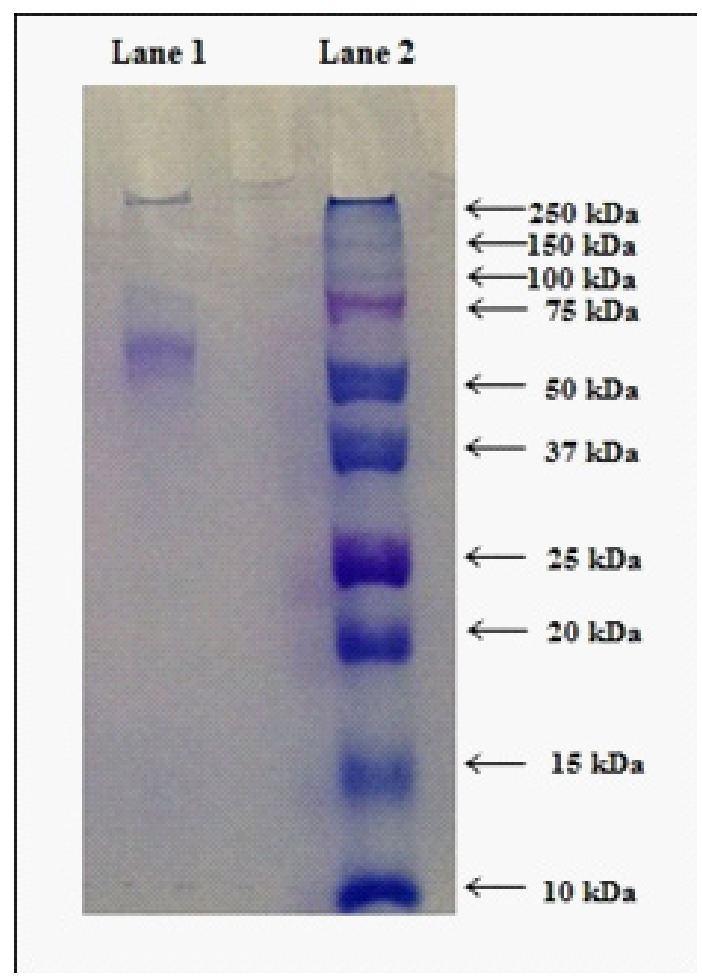

Figure 2: SDS-PAGE analysis - Lane 1: IEC protein fraction, Lane 2: Molecular marker.

\section{Molecular weight $(\mathrm{Mw})$ of protein}

The fraction of protein showing highest concentration in ionexchange chromatography was subjected to MALDI-TOF/MS analysis and the molecular weight of the unknown protein was found to be 53-54 kDa by MALDI-TOF mass spectrometry technique as shown in Figure 3.

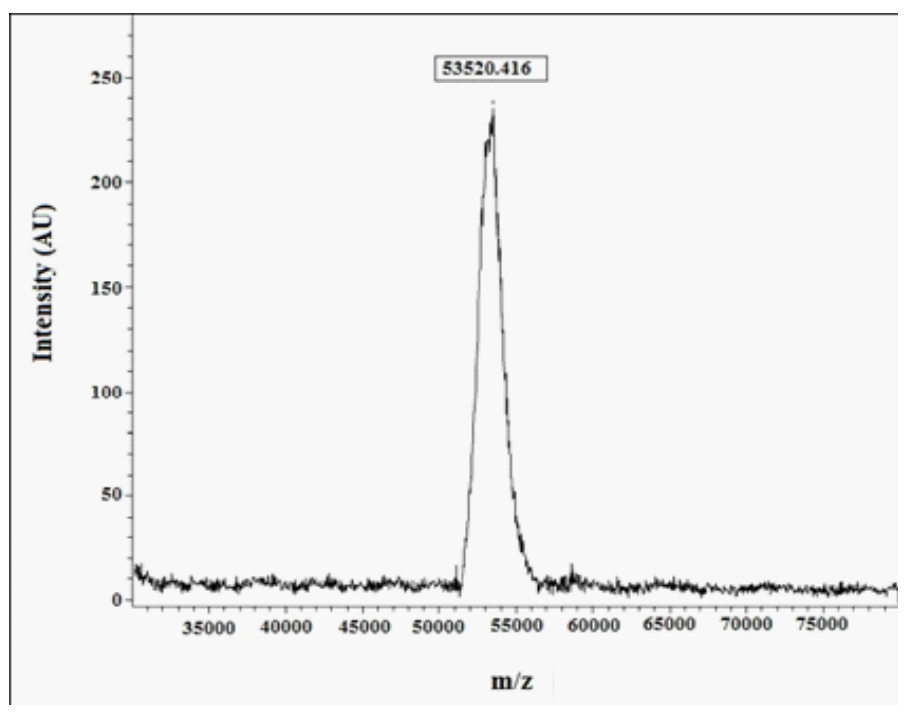

Figure 3: Molecular weight of purified protein by MALDI-TOF/ MS analysis

\section{Isoelectric point (pl) of protein}

Protein concentration was observed in the $7^{\text {th }}$ fraction whereas the remaining fractions revealed no protein content. Thus, the $\mathrm{pH} 5.5$ of the $7^{\text {th }}$ fraction was the respective $\mathrm{pl}$ of the protein. The result was identical to the estimated $\mathrm{pl}$ value of MRJP1 of Apis cerena (AcMRJP1) [20].

\section{$\mathrm{N}$-terminal sequence of protein}

The $\mathrm{N}$-terminal sequence of purified protein in the present study was found to be -N-I-L-R-G-E-S-L-N-K-S-L-P-I-L-H-E-W-K-Fby Edman's degradation. BLASTP analysis of these 20 amino acid FASTA sequences showed similarity among members of Apis dorsata, Drosophila melanogaster, Apis florea and Apis cerana protein family (Table 2 ). The obtained sequence shows similarity with S-I-L-R-G-E-S-L-D-K, the N-terminal sequence of MRJP1 deduced from Apis cerena [21]. The obtainedamino acid sequence of the 20 amino acids showed non-polar to polar amino acid ratio of 9:11. From the result it can be inferred that, the purified protein has more hydrophilic regions for interaction in the $\mathrm{N}$-terminal sequence reflecting a low percentage of nonpolar residues in this protein.

Table 2: N-terminal sequence of purified protein by Edman's degradation.

\begin{tabular}{|c|c|c|c|c|}
\hline Organism & Protein & N-terminal sequence & Similarity \\
\hline Apis cerana & MRJP 1 & SILRGESLNKSLSVLHEWKF & $96 \%$ \\
\hline Apis dorsata & MRJP 10 & PENSSRNLANSLNVIHEWKY & $79 \%$ \\
\hline Apis florea & MRJP 1 & SILRGESLNKSLNVLHEWKF & $94 \%$ \\
\hline Drosophila melanogaster & Yellow protein & YSWNQLDFAFPNTRLKDQAL & $88 \%$ \\
\hline
\end{tabular}




\section{Identification of protein}

The purified protein of $55 \mathrm{kDa}$ had significant similarity with the reported literature as Major Royal Jelly Protein 1 (MRJP1) or royalactin of Apis mellifera. This protein was further analyzed through MALDI-TOF mass spectrometric analysis. MASCOT search program showed a significant-top score of 77 as depicted in Figure $4(A)$ with protein sequence coverage of $25 \%$ and 14 peptide matches showed in Figure 4(B).
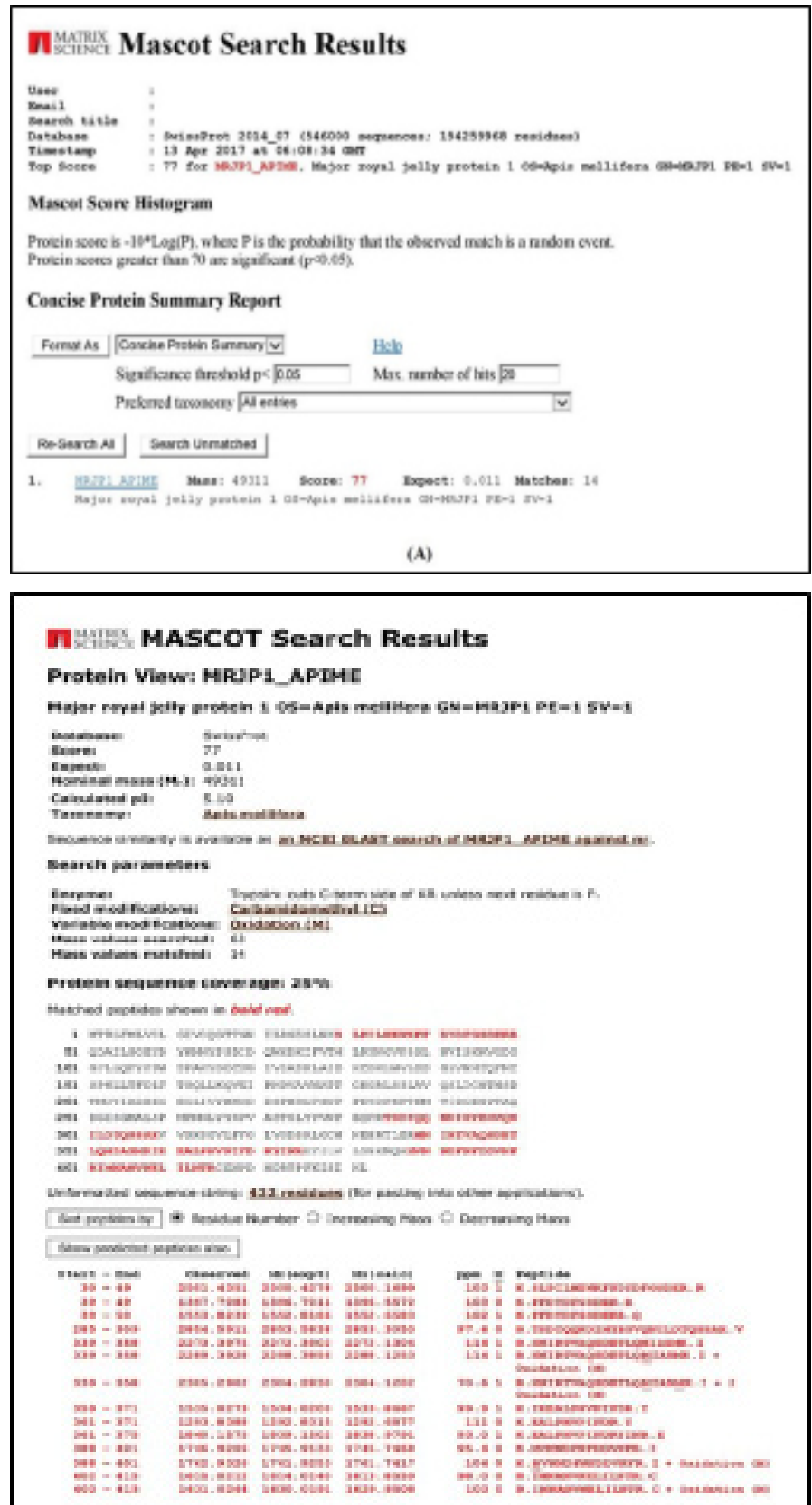

B

Figure 4: Mascot search results showing MRJP1 as identified protein: (A) Mascot Search program showing identified protein with significant score (B) Protein sequence coverage and peptide matches

\section{Antioxidant activity}

The honey, purified protein and protein hydrolysate/peptides obtainedafter tryptic digestion was subjected to analysis forevaluation of antioxidant activities by DPPH assay, FRAP assay, and ABTS assay. The results revealed protein hydrolysate/ peptides to have higher DPPH activity, FRAP reducing power and ABTS scavenging activity compared to the purified protein (Table 3).

The higher \% inhibition value of peptides might be because of the increased solvent accessibility of amino acids due to disruption of the tertiary structure of protein leading to free radical scavenging.

The reducing capacity of peptides was noted to be higher than the purified protein. The reason for such difference may be the specific composition of amino acid and the smaller size of peptides compared to higher molecular weight protein. The results reveal that peptides act as good electron donor and can act as strong reducing agent.

The ABTS scavenging activity of the peptides were reported to be higher than protein, which may be because of the amino acid side chain, chain length, and hydrophobicity.The amino acid composition of protein hydrolysate is also an important factor contributing to its antioxidant activity [22].

However, crude honey was shown to exhibit higher antioxidant activity than purified protein and protein hydrolysate which may be due to the presence of enzymes like catalase, peroxidase, and non-protein antioxidants such as phenolics, flavonoids, carotenoids, organic acids and vitamin C.

Table 3: Bioactive properties of honey, purified protein, and peptides.

\begin{tabular}{|c|c|c|c|}
\hline & \multicolumn{3}{|c|}{ Sample } \\
\hline Bioactivity assays & Honey & Protein & Peptides \\
\hline DPPH (\%) & $73.16 \pm 4.23$ & $59.71 \pm 6.38$ & $68.55 \pm 4.01$ \\
\hline FRAP (Fe [II] $\mu \mathrm{M})$ & $1000.87 \pm 71.48$ & $386.38 \pm 73.61$ & $402.91 \pm 6.55$ \\
\hline ABTS (\%) & $59.37 \pm 2.05$ & $49.25 \pm 3.22$ & $52.82 \pm 1.74$ \\
\hline
\end{tabular}

Data represented as mean \pm standard deviation based on three measurements $(n=3)$.

\section{Conclusion}

The protein extracted from Litchi chinensis honey (monofloral) was a major proteinpresent in honey. The isolated protein of $55 \mathrm{kDa}$ was identified as MRJP1, SDS-PAGE examination of which confirmed it to be a monomer. The purified protein had $\mathrm{pl}$ of 5.5 and the $\mathrm{N}$-terminal sequence suggested the protein to be hydrophilic in nature. Moreover, the protein, upon digestion with trypsin yielded hydrolysates or peptides with significant antioxidant activity. The hydrophobicity, specific amino acid composition, molecular weight and chain length are factors responsible for the antioxidant activity of peptides, which if orally available can be used for preventing and treating chronic diseases resulting due to oxidative stress. The isolated protein confirms its non-addictive nature. Thus, honey can be recommended as one of the food ingredients for regular consumption.

\section{Acknowledgement}

The authors gratefully acknowledge the Council of Scientific \& Industrial Research [Grant no. 38(1355)/13/EMR-II dated 14.02.2013], Govt. of India, New Delhi, India for the financial support provided to Ms. Debalina Bose for the grant of her fellowship. 


\section{References}

1. Gordon EL, Ariel-Donges AH, Bauman V, Merlo LJ. What Is the Evidence for "Food Addiction?" A Systematic Review. Nutrients. 2018; 10: 477.

2. Bird SP, Murphy M, Bake T, Albayrak O, Mercer JG. Getting science Getting Science to the Citizen - 'Food Addiction' at the British Science Festival as a Case Study of Interactive Public Engagement with High Profile Scientific Controversy. Obes Facts. 2013; 6: 103-108.

3. Meule A. How Prevalent is "Food Addiction"?. Front Psychiatry. 2011; 2: 61.

4. Avena NM, Rada P, Hoebel BG. Sugar and fat bingeing have notable differences in addictive-like behavior. J nutr. 2009; 139: 623-628.

5. Ziauddeen H, Farooqi IS, Fletcher PC. Obesity and the brain: how convincing is the addiction model? Nat Rev Neurosci. 2012; 13 279-286.

6. Lerma-Cabrera JM, Carvajal F, Lopez-Legarrea P. Food addiction as a new piece of the obesity framework. Nutr J. 2015; 15.

7. Pelchat ML. Food addiction in humans. J Nutr. 2009; 139: 620622.

8. Johnson PM, Kenny PJ. Dopamine D2 receptors in addiction-like reward dysfunction and compulsive eating in obese rats. Nat neurosci. 2010; 13: 635-641.

9. Randolph TG. The descriptive features of food addiction - addictive eating and drinking. Q J Stud Alcohol. 1956; 17: 198-224.

10. DiNicolantonio JJ, O'Keefe JH, Wilson WL. Sugar addiction: is it real? A narrative review. Br J Sports Med. 2018; 52: 910-913.

11. Arısoy S, Çoban I, Üstün-Aytekin O. Food-Derived Opioids: Production and the Effects of Opioids on Human Health, From Conventional to Innovative Approaches for Pain Treatment, Marco Cascella, IntechOpen. 2019.

12. Destoop M, Morrens M, Coppens V, Dom G. Addiction, Anhedonia, and Comorbid Mood Disorder. A Narrative Review. Front Psychiatry. 2019; 10.

13. Pursey KM, Collins CE, Stanwell P, Burrows TL. Foods and dietary profiles associated with 'food addiction' in young adults. Addict Behav Rep. 2015; 2: 41-48.
14. Nehete JY, Bhambar RS, Narkhede MR, Gawali SR. Natural proteins: Sources, isolation, characterization and applications. Pharmacogn Rev. 2013; 7: 107-116.

15. Meng XY, Zhang HX, Mezei M, Cui M. Molecular docking: A powerful approach for structure-based drug discovery. Curr Comput Aided Drug Des. 2011; 7: 146-157.

16. Bradford MM. A rapid and sensitive method for the quantitation of microgram quantities of protein utilizing the principle of protein-dye binding. Anal Biochem. 1976; 72: 248-254.

17. Laemmli UK. Cleavage of structural proteins during the assembly of the head of bacteriophage T4. Nature. 1970; 227: 680-685.

18. Guo H, Kouzuma Y, Yonekura M. Isolation and properties of antioxidative peptides from water-soluble royal jelly protein hydrolysate. Food Sci Technol Res. 2005; 11: 222-230.

19. Habib HM, Al Meqbali, FT, Kamal H, Souka UD, Ibrahim WH. Bioactive components, antioxidant and DNA damage inhibitory activities of honeys from arid regions. Food Chem. 2014; 153:2834.

20. Kashima Y, Kanematsu S, Asai S, Kusada M, Watanabe S, Kawashima T, Nakamura T, Shimada M, Goto T, Nagaoka S. Identification of a novel hypocholesterolemic protein, major royal jelly protein 1, derived from royal jelly. PLoS One. 2015; 9: e105073.

21. Srisuparbh D, Klinbunga S, Wongsiri S, Sittipraneed S. Isolation and characterization of major royal jelly cDNAs and proteins of the honey bee (Apis cerana). J Biochem Mol Biol. 2003; 36: 572579 .

22. Ulagesan S, Kuppusamy A, Kim HK. Antimicrobial and antioxidant activities of protein hydrolysate from terrestrial snail Cryptozonabistrialis. J. Appl. Pharm. 2018; 8: 012-019. 